\title{
OPPILAIDEN KAIKUPUHEEN TEHTÄVÄT KIELELLISESTI EPÄSYMMETRISISSÄ LUOKKAHUONEKESKUSTELUISSA
}

\author{
Tanja Vehkakoski, Jyväskylän yliopisto \\ Anja Rantala, Jyväskylän yliopisto
}

\begin{abstract}
Keskustelukumppanin puheen toistaminen tarjoaa henkilölle, jolla on käytössään rajalliset kielelliset resurssit, mahdollisuuden osallistua aktiivisesti keskusteluun. Tällaiseen toistamiseen on suhtauduttu aikaisemmissa tutkimuksissa kahtalaisesti: sitä on pidetty joko ei-toivottuna ja poisopittavana ekolalisena puheena tai sen on uskottu palvelevan kielitaidoltaan heikomman keskustelijan vuorovaikutuksellisia tavoitteita. Tässä artikkelissa tarkastellaan, mitä oppilaiden kaiuttavalla puheella tehdään ja miten opettajat vastaavat siihen luokkahuonekeskusteluissa. Tutkimusaineisto koostuu videotallennetuista oppitunneista autismiopetusryhmässä ( $\mathrm{N}=11)$ ja yksilöllisen opetuksen pienryhmässä $(N=9)$. Aineistossa oppilaat käyttivät kaikupuhetta responsseina joko opettajan uutta tietoa esitteleviin lausumiin, ohjaileviin lausumiin tai kysymyksiin. Vuorovaikutustilanteiden keskustelunanalyyttinen mikroanalyysi osoitti kaiuttamisen palvelevan orientoitumisena opettajan vuoroon, korjausaloitteena, itseä ohjaavana lausumana sekä sanojen opettelun keinona. Opettajien responssit oppilaiden kaikupuheeseen olivat pääasiallisesti lyhyitä ja sen nopeasti ohittavia. Opettajien taito tunnistaa kaikupuheen kommunikatiivisia tehtäviä on tärkeää, jotta lapsen toimijuus ja hänelle merkitykselliset asiat saisivat tilaa keskustelussa.
\end{abstract}

Avainsanat: kaikupuhe, keskustelunanalyysi, luokkahuonevuorovaikutus, opettaja, oppilas, toisto

Kirjoittajien yhteystiedot:

Tanja Vehkakoski, KT, dosentti, yliopistonlehtori Jyväskylän yliopisto, Kasvatustieteiden laitos / erityispedagogiikka

PL 35 (Ruusupuisto), 40014 Jyväskylän yliopisto. tanja.vehkakoski@jyu.fi.

Anja Rantala, KT, lehtori

Jyväskylän yliopisto, Kasvatustieteiden laitos / erityispedagogiikka

PL 35 (Ruusupuisto), 40014 Jyväskylän yliopisto anja.rantala@jyu.fi.

\section{JOHDANTO}

Keskustelukumppanin käyttämien ilmaisujen toistaminen on yleinen keskustelun resurssi, jolla voidaan esimerkiksi orientoitua keskustelukumppanin vuoroon (Couper-Kuhlen, 1996; Svennevig, 2004; Tannen, 2007), vahvistaa aiemmin sanottua (Sorjonen, 1996), tehdä korjausaloite (Benjamin \& Walker, 2013; Haakana, Kurhila, Lilja \& Savijärvi, 2016; Lilja, 2010; Schegloff, 1997; Sorjonen, 1996) tai korostaa puhujan tiedollista auktoriteettia (Heritage \& Raymond, 2005; Stivers, 
2005). Tämän lisäksi toistoa ilmenee ekolalisena piirteenä erilaisissa neurologisissa tai psykiatrisissa häiriöissä, kuten Alzheimerin taudissa (Cruz 2010), frontotemporaalisessa dementiassa (Mikesell, 2010) tai autismissa (Grossi, Marcone, Cinquegrana \& Gallucci, 2012; Sterponi \& Kirby, 2015; Sterponi \& Shankey, 2014; Stribling, Rae \& Dickerson, 2007; Valentino, Shillingburg, Conine \& Powell, 2012). Ekolalia eli kaikupuhe on perinteisesti määritelty kielelliseksi häiriöksi, jolla tarkoitetaan merkityksetöntä, automaattista ja tahatonta toisen henkilön sanojen tai ilmausten toistamista (Grossi ym., 2012; Leung \& Wu, 1997). Lääketieteellisestä näkökulmasta kaikupuheelle ominaista on siis ei-kommunikatiivisuus (Saldert \& Hartelius, 2011), jolloin keskustelukumppanin vuoron tai oman aikaisemman ilmaisun toistaminen on asiaankuulumatonta tai epäolennaista keskustelun etenemisen kannalta (Stribling ym., 2007) sekä osin henkilön oman itsesäätelyn ulottumattomissa (Grossi ym., 2012). Käsitettä käytetään kuitenkin myös löyhemmin kuvaamaan ylipäätään sanojen tai fraasien toistoa (Saldert \& Hartelius, 2011).

Varhaisessa kaikupuhetta käsittelevässä tutkimuksessa keskityttiin tarkastelemaan lähinnä kaiuttavan puheen rakennetta ja piirteitä (Prizant, 1983). Sen sijaan viime vuosina tutkijat ovat kiinnittäneet huomiota puheen toistamisen merkitykseen etenkin autististen lasten vuorovaikutuksessa (esim. Saldert \& Hartelius, 2011; Sterponi \& Shankey, 2014) sekä kakkoskielisissä keskusteluissa (Lilja, 2010, 2014; Svennevig, 2004). Tässä artikkelissa seuraamme tätä tutkimusperinnettä tarkastelemalla kaikupuhetta ensisijaisesti yhtenä yksilön käytössä olevista kielellisistä resursseista, jolla voi olla moninaisia merkityksiä ja tehtäviä vuorovaikutuksessa (ks. esim. Stribling ym., 2007). Tutkimme kaikupuhetta erityisopetuksen luokkahuonekeskusteluissa silloin, kun oppilas spontaanisti ja oma-aloitteisesti toistaa opettajan tai koulunkäynninohjaajan vuoron tai sen osan. Tilanteet edustavat kielellisesti epäsymmetrisiä vuorovaikutustilanteita (ks. Leskelä \& Lindholm, 2012), joissa oppilaat hyödyntävät tuettua kommunikaatiota rajallisten kieli- ja vuorovaikutustaitojensa vuoksi. Tarkoituksena on tarkastella sekä kaiuttamisen merkitystä luokkahuonekeskusteluissa että opettajan tapoja vastata oppilaiden kaikupuheeseen. Opettajien ja oppilaiden vuorovaikutuksen tarkastelu on erityisen tärkeää, sillä useat tutkimukset osoittavat vuorovaikutuskumppanilla olevan suuri merkitys tuettua vuorovaikutusta tarvitsevan henkilön sosiaaliseen ja kommunikatiiviseen toimintaan (esim. Leskelä \& Lindholm, 2012; Saldert \& Hartelius, 2011; Sterponi \& Shankey, 2014). Tutkimuskysymyksemme muotoutuivat seuraavasti: 1) Millaisia tehtäviä oppilaiden kaikupuheelle muodostuu erityisopetuksen luokkahuonevuorovaikutuksessa? sekä 2) Miten opettajat ja koulunkäynninohjaajat vastaavat oppilaiden kaiuttaviin responsseihin?

\section{Kaikupubeen ilmenemismuodot}

Kaikupuhetta kielellisesti epäsymmetristen vuorovaikutustilanteiden osana tarkastelleissa tutkimuksissa on oltu kiinnostuneita siitä, mitä kaiuttamisessa toistetaan (Stribling ym., 2007), miten toistetaan (Sterponi \& Shankey, 2014), kenen ilmaisuja toistetaan (Stiegler, 2015; Stribling ym., 2007), milloin toistetaan (Prizant, 1983; Sterponi \& Shankey, 2014) sekä mikä aiheuttaa toiston ( Grossi ym., 2012; Sterponi \& Shankey, 2014). Toistojen on havaittu olevan joko sanallisia, prosodisia (Stribling ym., 2007) tai kuvin esitettyjä (Tarplee \& Barrow, 1999). Lisäksi kaikupuheesta erotetaan yleensä kaksi erilaista toiston muotoa suhteessa toistetun vuoron alkuperäiseen esittäjään: oman vuoron tai sen osan toistaminen (WTR =within-turn) tai keskustelukumppanin vuoron tai sen osan 
toistaminen $($ PTR $=$ prior turn) $($ Stribling ym., 2007). Oman puheen kaiuttaminen on usein yhden sanan toistamista, joka suuntautuu toiminnan aloittamiseen (esim. jonkin esineen saamiseen käteensä), toiminnan lopettamiseen, keskustelukumppanin huomion saamiseen (Bottema-Beutel, Louick \& White, 2015; Stribling ym., 2007) tai haluun korostaa jotakin asiaa ja siihen sitoutumista (Sterponi \& Shankey, 2014; Sorjonen, 1996). Keskustelukumppanin vuoron kaiuttamisessa taas henkilö voi toistaa joko lähiympäristössään olevien henkilöiden puhetta tai esimerkiksi mediasta kuulemiaan ilmaisuja (Stiegler, 2015; Stribling ym., 2007). Jos kyse on henkilölle suoraan puhuttujen sanojen, kuten esimerkiksi hänelle esitetyn kysymyksen elementtien toistamisesta, yksilö on yleensä tietoinen vuorovaikutustilanteen luonteesta ja häneen kohdistuvista odotuksista. Jos taas henkilö toistaa toisille ihmisille suunnattua puhetta, kyse on enemmänkin vaikeudesta suodattaa pois itseen liittymättömiä ympäristön ärsykkeitä (Grossi ym., 2012).

Kaiuttaminen voi olla joko täydellistä tai osittaista, ja jälkimmäisessä tapauksessa alkuperäistä ilmaisua voidaan enemmän tai vähemmän muokata kaiuttavassa puheenvuorossa (Couper-Kuhlen, 1996; Mikesell, 2009; Park, 2011; Stivers, 2005). Ilmaisujen muokkaaminen voi koskea niin niiden kieliopillisia piirteitä kuin niiden lausumisen prosodisia ominaisuuksia, kuten toiston sanomisen nopeutta, voimakkuutta tai rytmiä (Couper-Kuhlen, 1996; Sterponi \& Shankey, 2014; Stivers, 2005). Sanallinen ja prosodinen kaiutus voivat esiintyä yhdessä tai jompaakumpaa voidaan muuntaa tai toistaa toisesta riippumatta (Couper-Kuhlen, 1996). Esimerkiksi äänen vivahteiden vaihtelu mahdollistaa lapselle vallan lähennyttää, loitonnuttaa tai häivyttää toisen ääntä toistossaan ja liittyä näin keskustelukumppaniin tai etääntyä hänestä (Sterponi \& Shankey, 2014). Lisäksi muokatussa kaiuttamisessa edellistä vuoroa tai sen osia voidaan eri tavoin painottaa (Stivers, 2005) tai laajentaa uusilla ilmaisuilla (Stivers, 2005; Svennevig, 2004).

Kaikupuhe vaihtelee myös alkuperäisen ilmaisun ja toiston ajallisen viiveen suhteen. Välitön kaiuttaminen seuraa välittömästi tai lyhyen ajan kuluttua malli-ilmausta, kun taas viivästynyt kaiutus tuotetaan huomattavasti myöhemmin toisessa sekvenssissä tai toisena aikana (Prizant, 1983; Sterponi \& Shankey, 2014). Kaiuttamalla voidaan rakentaa myös moniosainen vuoro tai kertomus, jossa kertoja palaa toiston kautta aiemmin sanomaansa ja jatkaa näin alkuperäistä kerrontaansa jonkin tekemänsä muun lisäyksen jälkeen (Wong, 2000). Samalla tavoin viivästettyä kaiutusta voidaan käyttää vastavuoroisen vuorovaikutussuhteen vahvistamiseen silloin, kun esimerkiksi aikuisen ja lapsen tapa palata toistaen samaan kertomukseen tai sen repliikkeihin toimii yhteisten merkitysten välittäjänä (Tarplee \& Barrow, 1999). Nollapersoonan muodossa esitetyn viivästetyn kaiutuksen (esim. "pitää istua") taas on havaittu ilmenevän erityisesti perheen yhteisten käyttäytymissääntöjen ja -ohjeiden toistona eritoten jännitteisissä tilanteissa (Sterponi \& Shankey, 2014).

\section{Kaikupubeen tehtävät}

Eri tutkijoilla ja tieteenaloilla on erilaisia käsityksiä siitä, mitä kaikupuheella tarkoitetaan ja miten siihen tulisi suhtautua: pyritäänkö kaikupuhetta vähentämään (Foxx, Schreck, Garito, Smith \& Weisenberger 2004; McMorrow, Foxx, Faw \& Bittle, 1987; Valentino ym., 2012) vai nähdäänkö se vahvistamisen arvoisena vuorovaikutukseen osallistumisen tapana (Leung \& Wu, 1997; Stiegler, 2015). Aiemmissa tutkimuksissa on yhtälltä pyritty erottamaan ei-toivottu (esimerkiksi autistinen) kaikupuhe niin kutsutun normaalin 
tai kehityksellisen kaikupuheen muodoista. Toisaalta taas on analysoitu tämän tutkimuksen tavoin, millaisia merkityksiä ja tavoitteita kaiuttavalla toiminnalla on lapselle (Sterponi \& Shankey, 2014). Esimerkiksi Mikesell (2010) korostaa, että ilman perusteellista ymmärrystä kaiutuksen kontekstista on vaikea tietää, onko toiston käyttö merkityksetöntä ja siis aidosti ekolalista vai tietoista ja yksilölle merkityksellistä. Lapsen toiminta voi olla myös epäjohdonmukaista: esimerkiksi joskus hänen toistavat responssinsa voivat olla ekolalisia ja joskus taas merkityksellisiä, jolloin toisen osapuolen on vaikeampi tulkita niitä (Mikesell, 2010; Sterponi \& Shankey, 2014).

Kaikupuheen vuorovaikutuksellisista tehtävistä kielellisesti epäsymmetrisissä keskusteluissa on paljon näyttöä (ks. Prizant, 1983; Saldert \& Hartelius 2011; Sterponi \& Shankey, 2014; Stribling ym., 2007). Keskustelukumppanin vuoron tai sen sisältämien ilmaisujen kaiuttaminen tarjoaa henkilölle, jolla on rajoittuneet kielelliset valmiudet, mahdollisuuden osallistua aktiivisesti keskusteluun (Saldert \& Hartelius, 2011; Stribling ym., 2007) ja löytää oma tiensä vuorovaikutukseen (Sterponi \& Kirby, 2016). Kaiutus voi toimia merkkinä kuulemisesta ja toisen puheeseen orientoitumisesta sekä siitä, että henkilö ymmärtää puheen kohdistuneen nimenomaan hänelle (Mikesell, 2010; Stribling ym., 2007; Svennevig, 2004). Kyseessä voi olla myös keino hyväksyä toisen kontribuutio (Mikesell, 2010; Svennevig, 2004) tai osoittaa affektiivisuutta, kuten hämmästystä tai mielenkiintoa, puheen alla olevaan asiaan (Sterponi \& Shankey, 2014; Svennevig, 2004). Kaiutusten kautta on myös mahdollista tehdä korjausaloite ja antaa keskustelukumppanille palautetta aiemmasta vuorosta sekä laajentaa näin keskustelun teemoja (Saldert \& Hartelius, 2011; Svennevig, 2004). Korjausaloitteina toimivien toistojen tehtävät voivat liittyä toistetun sanan merkityksen selvittämiseen, kuulemiseen tarkistukseen tai muuhun, esimerkiksi erimielisyyteen liittyvään, neuvottelutarpeeseen (Lilja, 2010, 2014).

Vaikka autistiseen vuorovaikutukseen liittyy usein prosodian jäykkyys ja muuttumattomuus suhteessa puhetilanteeseen (Niemi, 2008), autististen lasten on havaittu kykenevän luomaan erilaisia merkityksiä ilmaisuille kaikupuheen prosodisten ja segmentaalisten (äännetaso) vaihtelujen kautta (Sterponi \& Shankey, 2014). Esimerkiksi kaiuttaessaan toisen henkilön ilmausta ääntä elävöittämällä lapsi voi ikään kuin omaksua toisen henkilön näkökulman, ja kaiutus voidaan nähdä eräänlaisena toisen henkilön perspektiivin ottamisen keinona (Sterponi \& Kirby, 2016). Samoin esimerkiksi nousevalla intonaatiolla lausuttu toisto viittaa usein hämmästyksen ilmaisemiseen tai kysymykseen (Saldert \& Hartelius, 2011; Svennevig, 2004), jolloin siihen odotetaan responssia keskustelukumppanilta. Vaikka myös laskevalla intonaatiolla sanotulla toistolla on havaittu symmetrisissä vuorovaikutustilanteissa voitavan osoittaa ongelma keskustelukumppanin vuorossa (Schegloff, 1997; Sorjonen, 1996), useimmiten sillä otetaan kuitenkin ainoastaan tieto vastaan ja päätetään samalla meneillään ollut toimintajakso (Svennevig, 2004).

Mikesellin $(2009,2010)$ mukaan yksilön on mahdollista kaiutuksen avulla myös osoittaa tietävänsä, että on hänen vuoronsa reagoida ja että häneltä odotetaan responssia. Näin ollen kaiuttamalla voidaan osoittaa tietämistä ja ymmärtämistä tai vastaavasti myös teeskennellä niitä hämmentäviksi koetuissa tilanteissa. Jälkimmäisessä tapauksessa jonkun henkilön toistoa sisältävää vuoroa saatetaan pitää ensin ongelmattomana, kunnes häneltä edellytetään ymmärtämisen osoittamista kehotukseen sisältyvän toiminnan tekemisen tai kysymykseen vastaamisen muodossa (Mikesell, 2009, 2010). 
Keskustelukumppanin vuoron osan kaiuttaminen voi olla osoitettu myös enemmän puhujalle itselleen kuin keskustelukumppanille (Stribling ym., 2007.) Esimerkiksi lapsi voi toistaa opettajan antamia ohjeita luokassa ja komentaa itseään opettajan sanoilla ikään kuin itseä koskevana kehotteena (self-echoic prompt) (Leung \& Wu, 1997; Sterponi \& Kirby, 2016). Samalla tavoin kaiutus voi olla keino opetella kieltä ja vahvistaa omaa pätevyyttä kielenkäyttäjänä (Leung \& Wu, 1997; Wong, 2000). Aina kehotuksen toistaminen ei kuitenkaan tarkoita siihen sitoutumista, vaan toistamista voidaan käyttää myös keinona harjoittaa autonomista toimijuutta ja puolustaa omaa episteemistä auktoriteettia ja asemaa (Mikesell, 2010; Sterponi \& Shankey, 2014) silloin, kun oikeus toimijuuteen vaarantuu ja keskustelukumppanit esittävät uskomuksen henkilön tiedonpuutteesta perusasioissa (Mikesell, 2010). Esimerkiksi Mikesell (2010) havaitsi toiston olevan dementiaa sairastaville aikuisille keino vastustaa heille esitettyä ilmaisua tilanteissa, joissa heille ehdotettiin, heiltä kysyttiin tai heille todettiin itsestään selviä asioita, joita ei yleensä kysytä, ehdoteta tai esitetä kompetentille ja toimintakykyiselle aikuiselle (esim. käsky "niele" mukin antamisen yhteydessä -> vastaus "nielen, nielen”) (ks. myös Prizant, 1983).

\section{MENETELMÄT}

Tämän tutkimuksen aineisto koostui videotallennetuista oppitunneista autismiopetusryhmässä ( $\mathrm{N}=11$ oppituntia) ja yksilöllisen opetuksen pienryhmässä (YPR, kehitysvammaisten lasten opetus) ( $\mathrm{N}=9$ oppituntia). Autismiopetusryhmässä oli viisi 3-6-luokkalaista oppilasta, joilla oli pääsääntöisesti 11 -vuotinen oppivelvollisuus. Opetuksesta vastasi erityisluokanopettaja tukenaan viisi koulunkäynnin ohjaajaa. Yksilöllisen opetuksen pienryhmässä opiskeli seitsemän 5-9-luokkalaista oppilasta ja yksi luokkaan tutustumassa ollut oppilas, joka ei ole mukana tässä tutkimuksessa. Kyseistä luokkaa ohjasi erityisluokanopettaja sekä kolme koulunkäynnin ohjaajaa. Molemmissa ympäristöissä käytettiin puheen lisäksi kuva- ja esinekommunikaatiota sekä tukiviittomia. Ryhmille oli tyypillistä oppituntien eripituisuus ja jakautuminen erilaisiin tuokioihin: osassa tuokioita oli mukana kaikki oppilaat, kun taas osassa oppilaat hajaantuivat joko pienempiin ryhmiin tai kahdenkeskisiin ohjaustilanteisiin opettajan tai ohjaajan kanssa. Kaikilta osallistujilta sekä oppilaiden huoltajilta kysyttiin kirjallinen suostumus tutkimukseen.

Tutkimusaineistosta otettiin varsinaisen analyysin kohteeksi ne välitöntä kaiuttamista edustavat sekvenssit, joissa joku oppilaista toisti oma-aloitteisesti opettajan tai koulunkäynninohjaajan aiemman vuoron tai sen osan omassa vuorossaan. Oppilaan toisen position vuoro luettiin toistoksi, jos se oli kokonaan tai lähes kokonaan identtinen aikuisen edeltävän vuoron tai sen osan kanssa, vaikka toistettavaa ilmaisua olisi uudelleenmuotoiltu jollakin tavalla (esim. sanan muuttaminen monikosta yksikkömuotoiseksi) tai sen prosodiset piirteet eroaisivat alkuperäisestä ilmauksesta. Oppilaista Mari autismiopetusryhmästä ja Daniel yksilöllisen opetuksen pienryhmästä (nimet muutettu) kaiuttivat eniten opettajien vuoroja. Muut aineistossa esiintyvät oppilaat (Ville ja Tuuli yksilöllisen opetuksen pienryhmästä sekä Saku ja Olli autismiopetusryhmästä) käyttivät toistoa satunnaisesti. Osa oppilaista ei reagoinut ollenkaan kaiuttavasti. Kaikki oppilaat puhuivat myös muuten eli toistava puhe oli vain yksi heidän vuorovaikutuksessa olemisen tavoistaan. Oppilaiden oman puheen toistamista ei aineistossa juurikaan esiintynyt, joten se jätettiin analyysin ulkopuolelle. Koska tutkimuksessa tarkastellaan kaikupuheen vuorovaikutuksellista rakentumista, tietoja ei kerätty oppi- 
laiden henkilökohtaisista ominaisuuksista, oppimisvalmiuksista tai mahdollisista diagnooseista. Vuorovaikutustilanteiden analyysi perustui siis ainoastaan videotallenteisiin ja niiden litteraatteihin.

Tutkimusaineisto analysoitiin keskustelunanalyyttisesti. Analyysissa oppilaan jokaista toistavaa vuoroa tarkasteltiin osana koko vuorovaikutusta, ja huomio analyysissa kiinnitettiin erityisesti siihen, miten toistavat ilmaisut suhteutuvat aiemmin sanottuun ja mitä seurauksia niillä on seuraaviin vuoroihin (ks. esim. Heritage, 2001). Kohdistimme analyysimme eritoten siihen, mitä oppilas toisti opettajan puheesta ja miten hän sen teki, miten opettaja lausui oppilaan toistaman ilmaisun omassa edellisessä vuorossaan (esim. prosodia) sekä millaisia sekventiaalisia seurauksia oppilaan toistavalla reagoinnilla oli (esim. miten opettaja otti oppilaan toistavan ilmaisun vastaan ja jatkoi sitä omassa vuorossaan). Tulkitessamme ja nimetessämme toiston vuorovaikutuksellisia tehtäviä, kiinnitimme vuorovaikutuksessa huomiota erityisesti seuraavaan kahteen seikkaan: 1) toistavan vuoron sekventiaaliseen kontekstiin ja asemaan (esim. ilmensikö oppilas toistoa tilanteessa, jossa hänen oli ylipäätään odotuksenmukaista ottaa vuoro vai keskeyttikö oppilas kaiuttamisellaan opettajan puheen) sekä 2) toiston vuorovaikutuksellisiin seurauksiin (esim. toistiko opettaja oppilaan kaiuttavan ilmaisun, korjasiko sitä vai jättikö hän sen huomiotta). Ajattelemme siis, että toiston tehtäviä ei pysty päättelemään pelkästään oppilaan toistavaa vuoroa tarkastelemalla, vaan opettajan responssit toistaviin vuoroihin rakentavat yhdessä oppilaan toiston kanssa sille merkityksen. Erityisesti toiston sekventiaalisella asemalla ja seurauksilla oli siis merkittävä rooli toistolle muodostuvia tehtäviä tulkittaessa (ks. esim. Saldert \& Hartelius, 2011; Sterponi \& Shankey, 2014).
Koska mikä tahansa vuorovaikutuksessa tapahtuva voi olla keskustelunanalyysin kannalta merkityksellistä (ks. Heritage, 1984, 242-243), aineistoesimerkkien litteroinnissa sovellettiin Seppäsen (1997) esittämää, kielenkäytön yksityiskohtiin menevää litterointitapaa. Lisäksi multimodaalista toimintaa (esim. katse, osoittaminen) kuvattiin opettajan ja hänen ilmaisujaan toistavan oppilaan osalta kaksoissulkeissa meneillään olevan puhunnoksen alapuolella (ks. Niemelä, 2011). Mikäli puhe ja multimodaaliset ainekset esiintyivät esimerkeissä samanaikaisesti, niillä on esimerkeissä yhteinen rivinumero ja multimodaalisen aineksen kuvaus on sisennetty alkamaan ajallisesti oikeasta kohdasta puhunnosta. Multimodaalisen toiminnan päättyminen taas saattaa sijoittua vaihtelevasti suhteessa puhuttuun kieleen.

\section{TULOKSET}

Oppilaiden kaikupuhetta esiintyi aineistossamme sekä koko ryhmän opetustilanteissa että kahdenkeskisissä opettajan tai koulunkäynninohjaajan ja oppilaan välisissä ohjaustilanteissa. Yleisimmin oppilas toisti opettajan edellisen vuoron viimeisen sanan. Tämän lisäksi oppilas saattoi toistaa minkä tahansa sanan opettajan edellisestä vuorosta riippumatta sen sijainnista vuorossa tai opettajan koko edellisen puheenvuoron. Jälkimmäisessä tapauksessa toistettava puheenvuoro oli enintään kolmen sanan mittainen. Toistettava sana saattoi kuulua mihin sanaluokkaan tahansa, mutta useimmiten se oli subjektin, objektin tai adverbiaalin asemassa oleva substantiivi.

Oppilaan toistavat vuorot toimivat responsseina joko opettajan uutta tietoa esitteleviin lausumiin, ohjaileviin lausumiin tai kysymyksiin. Toisto oli välitöntä eli se edusti toisen position responssivuoroa opettajan puheeseen. Esitämme seuraavissa alaluvuissa, millaisia tehtäviä oppilaiden toistavat reaktiot 
palvelevat ja miten opettajat tai koulunkäynninohjaajat vastaavat oppilaiden toistaviin vuoroihin. Koska se mitä toistavalla puheella tehdään ja millaisen merkityksen se saa vuorovaikutuksessa, näyttää liittyvän siihen, mitä opettaja on omassa edellisessä vuorossaan oppilaan myöhemmin toistamalla ilmaisulla tehnyt (esim. kysynyt, ohjaillut, esitellyt tietoa), esitämme kaiuttamisen tehtävät näiden sekventiaalisten kontekstien mukaisesti.

\section{Opettajan esittelevien lausumien toisto orientoitumisena opettajan jakamaan tietoon}

Oppilaiden toistavat responssit opettajan tai koulunkäynninohjaajan uutta tietoa esitteleviin lausumiin esiintyvät tyypillisesti opettajajohtoisissa ryhmätilanteissa, joissa opettajan tai koulunkäynninohjaajan lisäksi mukana on vähintään kaksi oppilasta. Esittelevissä lausumissaan opettaja tai ohjaaja nimeää tai määrittää jonkin asian tai käsitteen (esim. "tää pajunoksa täällä on pajunkissoja”), ku- vaa tulevaa tai mennyttä tapahtumaa (esim. "Tänään me leivomme (.) teemme taikinaa”) tai kertoo jostakin aiheesta (esim. ”Suomessa pääsiäiskokkoja on poltettu erityisesti juuri lankalauantaina”). Opettajan ilmaisun toistaminen toimii tällöin aktiivisen kuuntelemisen merkkinä, huomion kiinnittämisenä opettajan sanomaan asiaan ja ylipäätään orientoitumisena opettajan aikaisempaan vuoroon, mutta tulkintamme mukaan myös oppimisstrategiana, jolloin oppilaat mallintavat ja makustelevat opettajan tai koulunkäynninohjaajan tuottamia ilmaisuja.

Oppilaiden tyypillisin tapa käyttää toistoa responssina opettajan esitteleviin lausumiin ilmenee seuraavassa esimerkissä 1 , jossa on meneillään ympäristö-luonnontiedon tunti autismiopetusryhmässä. Paikalla on kaksi oppilasta sekä koulunkäynninohjaaja, joka kiinnittää taululle paperiarkin, johon on kirjoitettu pääsiäisen tapahtumia kuvaavia lauseita. Jokaisen lauseen sisältämän sanan yläpuolella on sitä vastaava kuva.

(1)

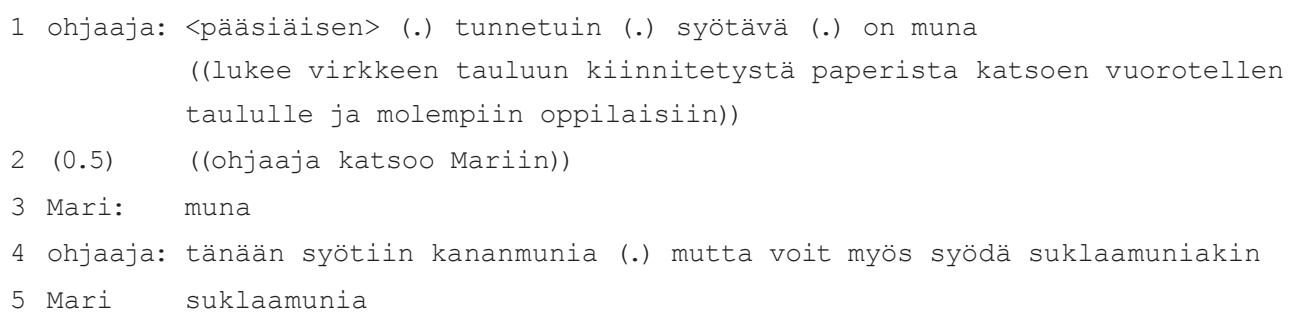

Esimerkin alussa ohjaaja lukee tauluun kiinnitetylle paperille kirjoitetun virkkeen: <pääsiäisen> (.) tunnetuin (.) syötävä (.) on muna. Lukemista seuraa lyhyt tauko, jonka aikana ohjaaja katsoo Mariin. Tämän jälkeen Mari toistaa ohjaajan lausumasta pääsiäisruokiin kuuluvan ja predikatiivin asemassa olevan substantiivin muna (rivi 3). Ohjaaja ei ole prosodisesti nostanut muna-sanaa virkkeestään erityisesti esille toisin kuin virkkeen ensimmäisen sanan, pääsiäisen, jonka hän on lausunut muita sanoja hitaammin. Lukemista seuraavan tauon ja ohjaajan katsekontaktin voi kuitenkin tulkita mahdollisuutena tai odotuksena ottaa vastausvuoro. Marin toiston jälkeen ohjaaja jatkaa kerrontaa antamalla esi- 
merkin sekä kananmunan että suklaamunan syömisestä. Näistä Mari tarttuu suklaamunaan toistaen sen samassa monikkomuodossa kuin mitä ohjaaja on käyttänyt. Toisto ei ole kuitenkaan täysin identtinen ohjaajan ilmaisun kanssa, vaan Mari jättää toistosta liitepartikkelin kin pois. Tämä osoittaa Marin pystyvän hahmottamaan ohjaajan puheen ydinsisällön jättämällä toistosta epäolennaisen aineksen pois. Vaikka ohjaajan vuorossa -kin -päätteellä oli tietoa lisäävä merkitys (koulussa syötyjen kananmunien lisäksi pääsiäisenä voidaan syödä myös suklaamunia), Marin vuorossa päätteen toistaminen on tarpeetonta.

Esimerkissä 1 Mari siis osoitti toistamisellaan olevansa kuulolla ja vastaanottavansa koulunkäynninohjaajan kerronnan pääsisällön. Toistavat vuorot eivät kuitenkaan muuttaneet koulunkäynninohjaajan toimintaa, eikä niistä annettu edes minimipalautetta. Seuraavassa esimerkissä 2 taas toisto rakentuu oppilaan orientaatioksi käsitteen oppimiseen. Esimerkki on yksilöllisen opetuksen pienryhmän biologian tunnilta, jolla käsitellään erilaisia eläinryhmiä, kuten kaloja, matelijoita ja lintuja. Paikalla on erityisluokanopettajan lisäksi kaksi oppilasta: Joni ja Ville. Oppilaat istuvat toisiinsa nähden kulmittain omissa pulpeteissaan ja opettaja heidän edessään omalla tuolillaan. Oppilailla on edessään pöydällä tuntiin liittyvät kirjat.

(2)

1 opettaja: LINNUILla on $\uparrow$ höyhenpeite

((osoittaa oikealla kädellään nopeasti Jonin kirjaan katsoen viistosti alaspäin Jonin pulpetinkanteen. Joni ja Ville katsovat viistosti alaspäin omiin pulpetinkansiinsa)) 
Esimerkissä 2 opettajan käyttämä adjektiivi ontto lintujen luita kuvattaessa nousee toisen oppilaista, Villen, huomion kohteeksi. Vaikka opettajan johdattelevan lauseen $>j a$ sit oli se $<$ imperfektimuoto, se-pronomi ja nopea sanominen antavat ymmärtää, että lintujen luiden onttoutta olisi sivuttu opetuksessa jo aiemmin, se merkitään vuorovaikutuksessa merkitykselliseksi adjektiiviksi. Ontto-adjektiivin merkityksellisyyteen suuntautuu ensin opettaja, joka artikuloi sen hitaammin ja selkeämmin kuin vuoronsa muut sanat. Opettajan vuoroa seuraavan lyhyen tauon jälkeen Ville suuntautuu samaan adjektiiviin toistamalla sen yhtä hitaasti ja selkeästi kuin opettaja (rivi 6). Toistettavan ilmauksen prosodisesta samankaltaisuudesta huolimatta toisto ei ole kuitenkaan mekaanista, vaan oppilaalle merkityksellinen avainsana toistetaan perusmuodossa opettajan käyttämän monikon partitiivin sijaan. Opettaja kuitenkin jatkaa vuoroaan osin Villen toiston kanssa päällekkäin rakentamalla kausaalista suhdetta luiden onttouden ja lentämisen välille eli perustelemalla luiden onttoutta lintujen lentämisen näkökulmasta.

Opettajan selityksen viimeisen lentääverbin kanssa päällekkäin Ville toistaa vielä uudelleen ontto-sanan samalla tavoin kuin aiemminkin. Villen toisto keskeyttää siis tällä kertaa opettajan selityksen, eikä ole tässä samalla tavoin sekventiaalisesti odotuksenmukainen toiminto kuin rivillä 6 tapahtuva sanaan orientoituminen. Opettaja jatkaakin ensin edelleen perustelujen antamista luiden keveydelle (et ne pysyy ilmassa), mutta käsittelee välittömästi tämän jälkeen Villen toistoa korjausaloitteena ja sanan ymmärtämisen ongelmana (ks. Haakana ym., 2016; Lilja, 2010, 2014). Hän päätyy Villeen päin kääntyen määrittelemään adjektiivin ontto merkityksen vertaamalla onttoa linnunluuta konkreettisempaan ja tutumpaan kohteeseen putki, visualisoimalla kädellään putken muotoa sekä kuvaamalla onttoa vielä tarkentavalla määreellä tyhjää täynnä.

Esimerkissä 2 opettaja ja Ville orientoituivat siis yhdessä ontto-sanan äärelle. Opettaja merkitsi adjektiivin prosodisesti merkittäväksi, minkä jälkeen Ville makusteli sitä puheessaan. Opettaja taas otti Villen toistavan puheen korjausaloitteena ja merkkinä termin jatkokäsittelyn tarpeesta sekä suuntasi opetustaan oppilaan toistamaan ilmaisuun selittämällä sen merkityksen ja laajentamalla kuvaustaan siitä. Siten Villen korjausaloite sai opettajan vielä määrittämään lopuksi onttoadjektiivin merkityksen niin sanan synonyymisen kuvauksen kuin visualisoimisenkin avulla. Tämän jälkeen sekvenssi päättyy ja opettaja siirtyy puhumaan lintujen tasalämpöisyydestä ja lisääntymisestä.

Seuraava aineistoesimerkki 3 on myös yksilöllisen opetuksen pienryhmästä. Kyseessä on aamupiiri, jossa on paikalla 8 oppilasta. Oppilaat istuvat puoliympyrässä ja opettaja seisoo heidän edessään. Oppilaista Daniel suuntautuu vahvasti opettajan ilmaisun yhteen sanaan, jonka toistamisen opettaja pyrkii sammuttamaan. Ennen esimerkkiä tunnilla on käyty läpi kuukauden vaihtumista maaliskuuksi ja opettaja on etsinyt maaliskuun kuvakorttia. 
(3)

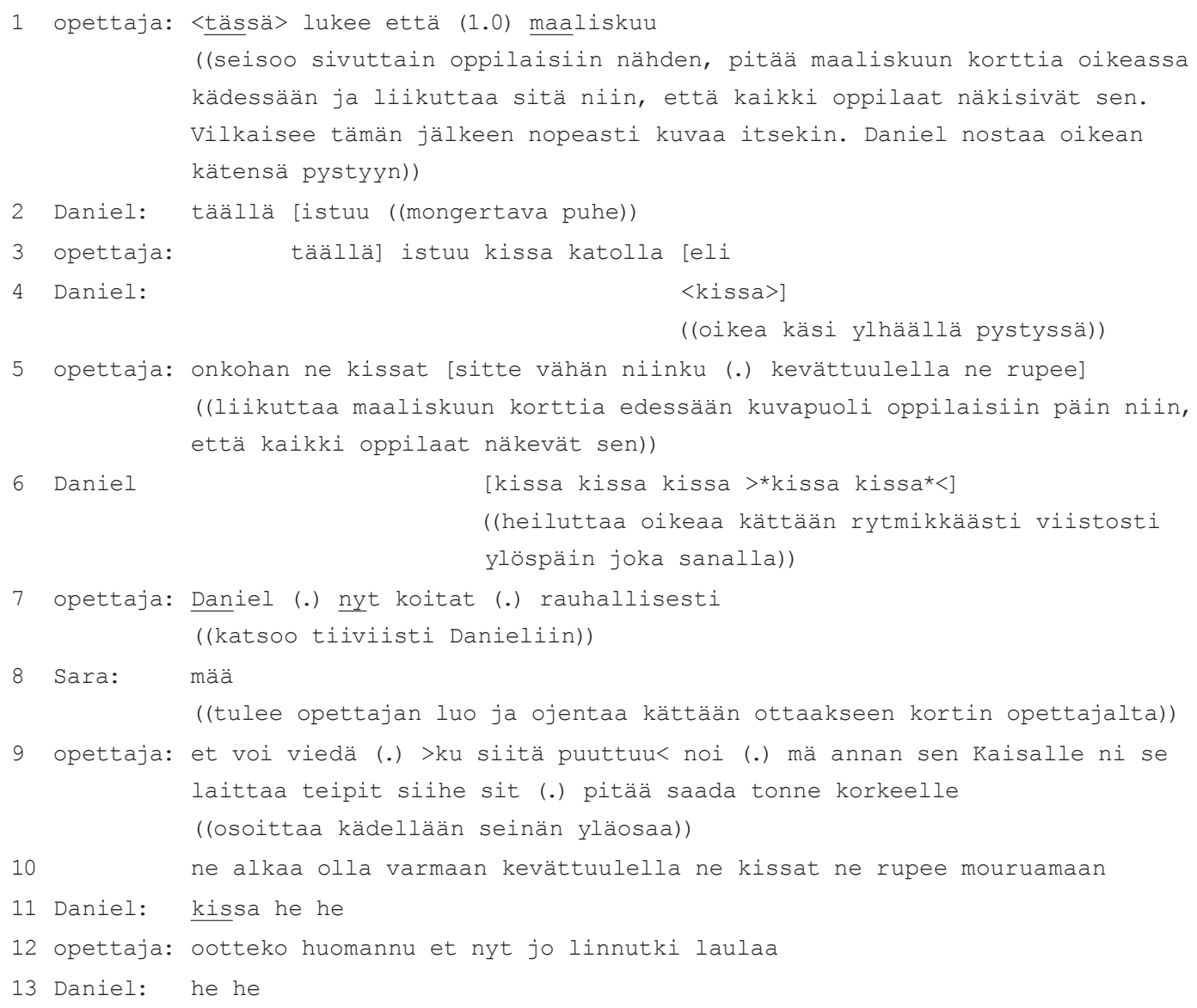

Esimerkin alussa opettaja näyttää oppilaille maaliskuun kuvakorttia, jossa kissa istuu talon katolla. Sekä Daniel että opettaja kiinnittävät huomiota kortin kuvaan, jonka sisällön sanoittamisen aloittaa ensin Daniel ja lopettaa opettaja osin päällekkäin Danielin kanssa puhuen. Daniel kiinnittää opettajan kuvailevassa vuorossa huomionsa kissa-sanaan, joka sijaitsee opettajan väitelauseen täällä istuu kissa katolla keskellä. Opettaja ei ole mitenkään korostanut lauseen subjektia, kissaa, omassa vuorossaan, mutta kissa esiintyy opettajan näyttämän kortin kuvassa.

Danielin ensimmäinen kissa-sanan toisto rivillä 4 osuu päällekkäin opettajan sanoman lausumapartikkelin eli kanssa, mikä viittaa sii- hen, että opettaja on lisäämässä vielä jotakin edellä sanomaansa. Seuraava Danielin kissasanaa toistava vuoro tapahtuu päällekkäin opettajan useamman sanan mittaisen vuoron kanssa (rivi 6). Tämä Danielin toistava vuoro on luonteeltaan affektiivinen: Daniel kohottautuu ylös tuolistaan ja heiluttaa oikeaa kättään rytmikkäästi ja viistosti ilmaan joka sanalla. Innostuksen jakamisesta ei muodostu kuitenkaan yhteinen kokemus opettajan kanssa, vaan opettaja torjuu Danielin aloitteen välitöntä rauhoittumista edellyttävässä työrauhavuorossaan rivillä 7: Daniel (.) nyt koitat (.) rauhallisesti. Opettajan direktiiviä ja tiukkaa katseen kohdistamista Danieliin seuraa välisekvenssi, jossa opettaja neuvotte- 
lee toisen oppilaan, Saran, kanssa maaliskuun kuvan laittamisesta taululle (rivit 8-9). Välisekvenssin jälkeen opettaja palaa vielä kuvan teemaan rivillä 10, mikä saa Danielin jälleen kerran toistamaan kissa-sanan naurun säestämänä. Tätä naurua Daniel jatkaa vielä senkin jälkeen, kun opettaja on vaihtanut jo puhetta toiseen kevään merkkiin, lintujen lauluun.

Tässä esimerkissä Danielin kissa-sanan toisto näyttäytyi keinona osoittaa myönteistä suhtautumista, kuten innostuneisuutta ja mielenkiintoa, toistettavaa sanaa kohtaan. Danielin affektiivisesti latautunut osallistuminen näkyi ensimmäisen kerran jo rivillä 1 hänen nostaessaan oikean kätensä pystyyn maaliskuun kuvakortin nähdessään. Tämän jälkeen kissa-sanan toisto sekä siihen liittyvät fyysiset eleet ja nauru vahvistavat tulkintaa Danielin innostuneisuudesta. Lisäksi Danielin toiminta voisi palvella myös topikalisointivihjeenä (ks. Svennevig, 2004) eli pyrkimyksenä nostaa kissa puheenaiheeksi ja edelleen kehittelyn kohteeksi, mutta opettaja ei tartu tähän. Danielin reagoinnin hallitsevuus, mielenkiinnon herättäneen sanan usea toisteleminen ja toiston sekventiaalisen sijainnin epäodotuksenmukaisuus saattavat olla syy siihen, että vaikka opettajan responssit esittävien lausumien toistoon ovat tyypillisesti minimaalisesti vahvistavia tai ne hiljaa ohittavia, toisto otetaan tässä häiritsevänä käyttäytymisenä, johon reagoidaan työrauhavuorolla. Lisäksi se, että aamupiirin aiheena ei ole varsinaisesti kissa, vaan ajan ja kuukausien jäsentäminen, saattaa johtaa siihen, ettei opettaja kysy lisää tai muutoin jatka keskustelua Danielin toistamasta kissa-sanasta.

\section{Opettajan objailevien lausumien toisto oman toiminnan objauksena}

Oppilaiden toistaville responsseille opettajan tai koulunkäynninohjaajan esittämiin ohjaileviin lausumiin on tyypillistä se, että niihin liittyy toistettavan ohjailevan lausuman mukainen toiminta joko toistavan ilmaisun kanssa samanaikaisesti tai välittömästi sen jälkeen. Toisto palvelee tällöin eräänlaisena oppilaan toiminnanohjauksellisena itsepuheena, jolloin oppilas toistaa opettajan ohjailevan lausuman ja toimii samalla sen mukaisesti. Seuraava esimerkki 4 on autismiopetusryhmän opetustuokiolta, jossa on mukana erityisluokanopettaja, koulunkäynninohjaaja sekä kaksi oppilasta. Kaikki istuvat saman pyöreän pöydän ääressä: opettajan vieressä hänen vasemmalla puolellaan istuu Olli ja vähän kauempana opettajan oikealla puolella istuu Saku ja ohjaaja hänen vieressään. Opettaja on päättelemässä tuokiota ja on juuri sulkenut Ollin vihkon.

\section{(4)}

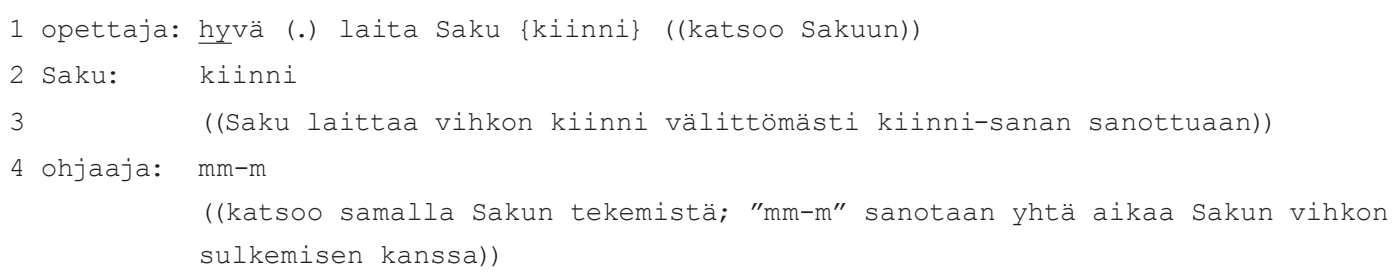


Esimerkin 4 alussa opettajan sanoma adjektiivi hyvä toimii siirtymäkommenttina, jonka jälkeen opettaja kohdistaa käskyn Sakulle sekä hänet nimeltä mainiten että häneen katsoen. Lisäksi opettaja tukiviittoo käskylauseen sisältämän suuntaa ilmaisevan adverbin kiinni ja merkitsee sen näin ymmärtämisen kannalta olennaiseksi asiaksi. Saku toistaakin viitotun ja puhutun suunnan ilmaisun kiinni ikään kuin itselleen suunnattuna ohjailevana lausumana (rivi 2) ja välittömästi sen sanottuaan tarttuu edessään pöydällä olevaan vihkoonsa ja sulkee sen. Sakun vieressä istuva koulunkäynninohjaaja seuraa katseellaan Sakun tekemistä ja antaa siitä hyväksyvän minimipalautteen $m m$ yhtä aikaa vihkon sulkemi- sen kanssa. Saku siis toisti opettajan antaman käskyn sisältämän suunnan ilmaisun kiinni, otti sen itseä koskevaksi direktiiviksi ja toimi välittömästi sen mukaisesti.

Seuraava esimerkki 5 on yksilöllisen opetuksen pienryhmän aamupiiristä. Mukana on viisi oppilasta sekä erityisluokanopettaja. Oppilaista neljä istuu puoliympyrässä tuoleillaan, kun taas yksi oppilaista (Ville) on luokan edessä selin muihin oppilaisiin etsimässä pöydällä olevassa pienessä muovikorissa olevista kuvakorteista kastikkeen kuvaa. Esimerkin alussa opettaja siirtyy Villen oikealle puolelle viemään samaisen pöydän päälle kuvataulun. Tällöin Ville ottaa kontaktin opettajaan.

(5)

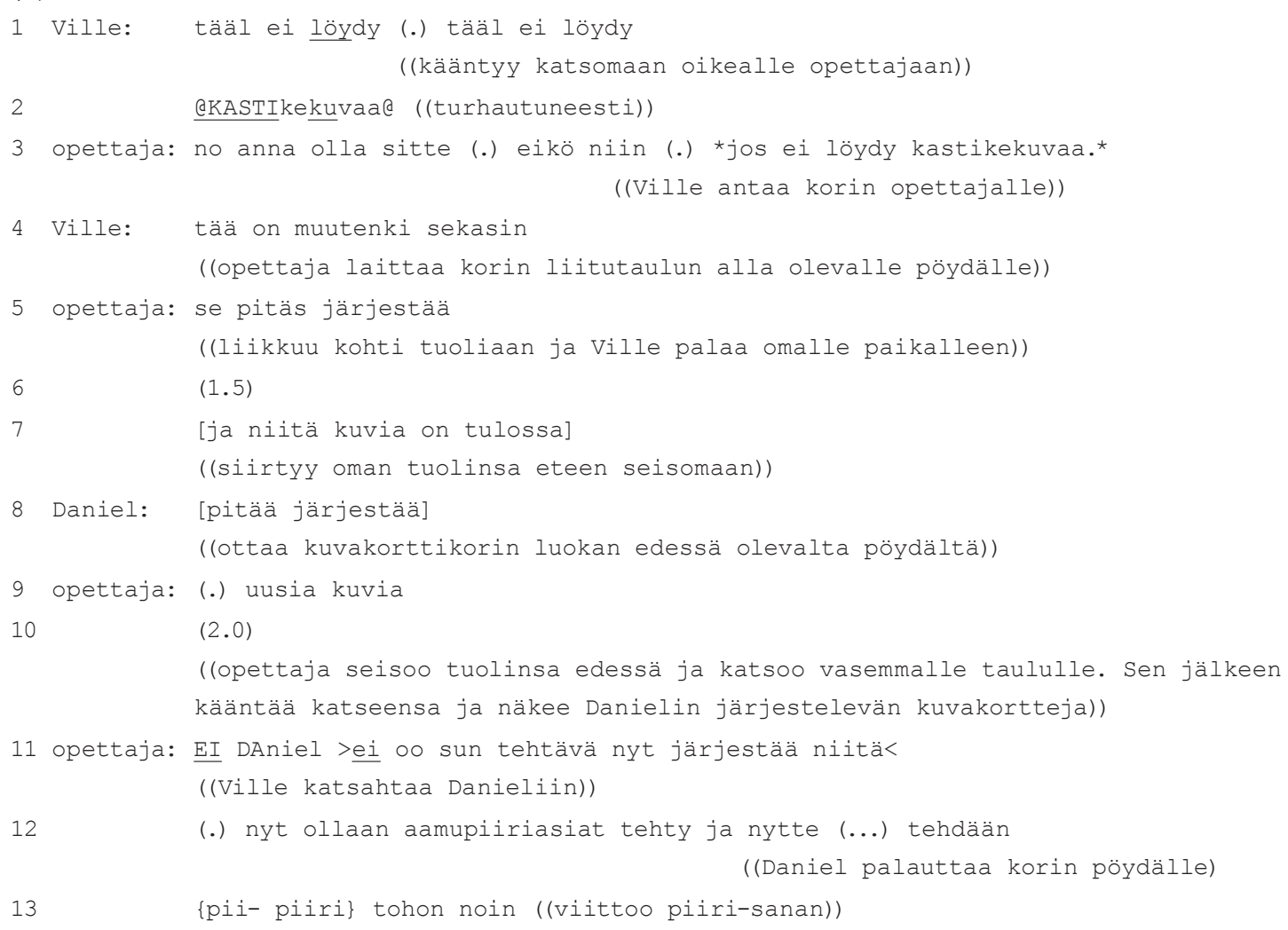


Esimerkki alkaa Villen ja opettajan kahdenkeskisestä keskustelusta, joka koskee kastike-kuvan etsimistä kuvakorista. Luovuttuaan kuvan etsimisestä turhautuneelta vaikuttava Ville esittää tekemänsä huomion kuvien järjestyksen sekavuudesta korissa: tää on muutenki sekasin. Opettaja vahvistaa huomion esittämällä tulevaa toimintaa koskevan suosituksen: se pitäs järjestä̈̈. Suosituksen esittäminen konditionaalimuotoisena nollapersoonalauseena viittaa siihen, että kuvien järjestäminen on ainoastaan yksi vaihtoehto tilanteessa ja velvollisuus siihen koskee periaatteessa ketä tahansa, niin opettajaa kuin tilanteessa mukana olevia oppilaitakin (ks. VISK, 2004, § 1348, § 1590). Daniel ottaa kuitenkin ilmaisun itseään koskevana kehotuksena toistamalla nesessiiviverbin pitäisi ehdottomampaa velvoitetta ilmaisevassa indikatiivi-muodossa pitää (rivi 8). Samalla hän ryhtyy lausuman sisältämään toimintaan kurkottaen kädellään korin liitutaulun edessä olevalta pöydältä ja alkaen järjestämään sen kuvia. Opettaja huomaa Danielin toiminnan vasta hetken kuluttua ja kieltää Danielia painokkaasti kieltosanalla $\underline{E I}$ sekä antaa kiellolleen perustelun järjestämisen väärään ajankohtaan ja väärään toimijaan vedoten ( $\underline{e i}$ oo sun tehtävä nyt järjestää niitä). Pienen viiveen jälkeen Daniel palauttaakin korin takaisin paikalleen.

Samoin kuin esimerkissä 4, myös tässä Daniel toimi siis toistetun ilmaisun sisältämän velvollisuuden mukaisesti. Danielin opettajan lausumalle antama merkitys ei kuitenkaan vastannut opettajan sille antamaa merkitystä, joten toiston mukainen tekeminen keskeytettiin. Seuraavassa esimerkissä taas Mari kyllä toistaa koulunkäynninohjaajan ohjeen, mutta ei kuitenkaan toimi sen mukaisesti. Autismiopetusryhmään sijoittuvassa esimerkissä koulunkäynninohjaaja ja Mari työskentelevät vierekkäin saman soikean muotoisen pöydän äärellä. Mari on kirjoittamassa vihkoonsa tekstiä "pääsiäisaiheisia kuvia" ennen aiheeseen liittyvien kuvien liimaamista siihen.

\section{(6)}

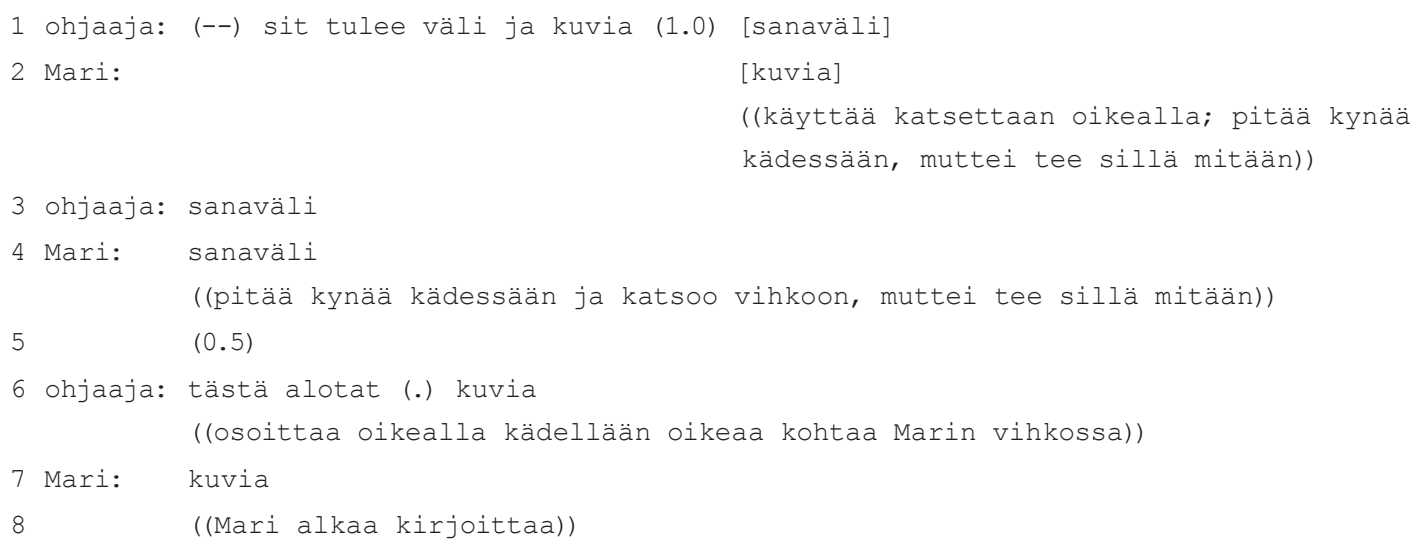


Esimerkin 6 alussa koulunkäynninohjaaja antaa Marille ohjeen lauseen kirjoittamiseksi vihkoon: sit tulee väli ja kuvia. Ohjeistus tarkoittaa, että Marin juuri kirjoittaman sanan jälkeen tulee vihkoon väli, ennen kuin siihen kirjoitetaan sana kuvia. Ohjeistusta seuraa tauko, jonka jälkeen ohjaaja toistaa aikaisemmin sanomansa termin väli tarkemmassa muodossa sanaväli. Vaikka ilmaisu on verbitön, se on tilanneyhteydestä pääteltävissä ohjeen kaltaiseksi direktiiviksi.

Mari toistaa rivillä 2 ohjaajan väli-sanan uudelleenmuotoilun kanssa päällekkäin tämän edellä mainitseman sanan kuvia. Vaikka kuvia on yksi vihkoon kirjoitettavista sanoista, Marin toisto ei yhdisty tässä sanan kirjoittamiseen vihkoon, vaan jää irralliseksi. Ohjaaja päätyykin toistamaan uudelleen ohjeen sanaväli (rivi 3), jonka myös Mari toistaa nyt välittömästi. Hän ei kuitenkaan aloita vieläkään kirjoittamista, mutta katsoo kynä kädessä vihkoaan. Pienen tauon jälkeen ohjaaja konkretisoi ja visualisoi ohjailevaa lausumaansa: hän osoittaa toisella kädellään oikeaa kohtaa Marin vihkossa ja antaa välitöntä toimintaa edellyttävän neuvon yksikön toisessa persoonassa: tästä alotat. Lisäksi hän vielä mainitsee uudelleen vihkoon kirjoitettavan sanan kuvia. Tämä saa Marin toimimaan: hän toistaa kuvia-sanan ja alkaa välittömästi tämän jälkeen kirjoittaa sanaa vihkoonsa.

Marin ensimmäistä kuvia ja sanaväli -sanojen toistoa voidaan tässä pitää ymmärryksen esittämisenä, muttei sen osoittamisena. Vaikka Mari siis esitti toistollaan orientoituvansa koulunkäynninohjaajan vuoroon ja sen sisältämään tietoon, hän epäonnistui tunnistamaan ohjaajan vuoron ohjeena, joka velvoittaisi häntä toimimaan sen mukaisesti (ks. myös Mikesell, 2009, 2010). Tällöin Marin toisto oli jollain tapaa yhteensopimaton ohjaajan vuoron kanssa: hän kyllä suuntautui vuoron sanojen sisältöön, muttei niiden välittämään ohjaavaan merkitykseen. Samalla
Marin odotustenvastainen toiminta palveli ohjaajalle merkkinä ymmärryksen ongelmasta ja toimi näin korjausaloitteena. Toistetun ilmauksen tulkitseminen korjausaloitteeksi ilmeni siinä, miten ohjaaja korjasi toiston jälkeen omaa puhettaan tarkentamalla antamaansa ohjetta sekä sanallisesti että visuaalisesti (ks. esim. Lilja, 2010, 99).

\section{Opettajan esittämien kysymysten toisto korjausaloitteena}

Toistavissa responsseissa kysymyksiin oppilas toistaa opettajan tai koulunkäynnin ohjaajan esittämän kysymyksen tai sen osan siihen vastaamisen sijaan. Svennevig (2003) on kutsunut tällaista toistamista kaikuvastaukseksi. Tällaisessa yhteydessä oppilaan toistoa voidaan pitää odotusten vastaisena toimintana, joka keskeyttää vuorovaikutuksen sujuvan etenemisen. Opettaja tai ohjaaja pyrkiikin tyypillisesti palaamaan oppilaan toiston jälkeen alkuperäiseen kysymykseensä ja saamaan oppilaan vastaamaan siihen tarkoituksenmukaisesti toistamalla tai uudelleenmuotoilemalla sen, muuttamalla kysymystyyppiä tai antamalla vastaamiseen sanallisia tai visuaalisia vihjeitä. Tällöin oppilaan toisto toimii siis korjausaloitteena, jota seuraa opettajan yhteisen ymmärryksen saavuttamiseen tähtäävä korjausvuoro (ks. myös Lilja, 2010, 2014).

Seuraava esimerkki 7 on autismiopetusryhmän ympäristötiedon tunnilta, jossa on mukana koulunkäynnin ohjaaja sekä kaksi oppilasta: Mari ja Eetu. Kaikki istuvat saman pyöreän pöydän äärellä. Tuokiolla käydään kuvien avulla läpi pääsiäisviikon eri päiviä ja niihin liittyviä perinteitä. Taululle on kiinnitetty allekkain pääsiäisviikon eri viikonpäivien nimet omina sanalappuinaan. Viikonpäivät käydään läpi järjestyksessä ja kunkin viikonpäivä-sanakortin viereen kiinnitetään kuvia erityisesti kyseiseen päivään liittyvistä perinteistä. Seuraavaksi käsittelyssä on pääsiäissunnuntai. 
(7)

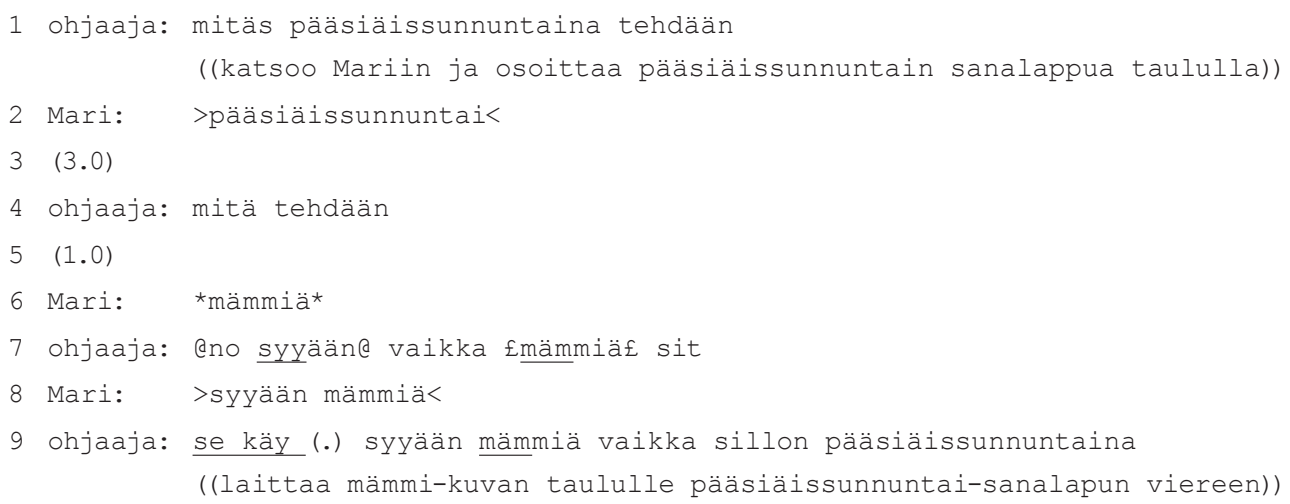

Esimerkin alussa koulunkäynninohjaaja esittää yleisen hakukysymyksen mitäs pä̈̈siäissunnuntaina tebdä̈n katsoen samalla Mariin ja osoittaen pääsiäissunnuntain sanalappua taululla. Mari ottaakin vuoron ja antaa kysymykseen nopean vastauksen, jossa hän toistaa pääsiäissunnuntai-aikamääreen perusmuodossaan ilman na-sijapäätettä (rivi 2). Seuraa 3 sekunnin tauko, minkä jälkeen ohjaaja kysyy saman kysymyksen kuin rivillä 1, mutta yksinkertaistaa sitä jättämällä siitä nyt pois Marin toistaman ajan ilmauksen pääsiäissunnuntai. Pienen tauon jälkeen Mari vastaa hiljaisella äänellä *mämmiä*. Tämän ohjaaja hyväksyy vastaukseksi, mutta uudelleenmuotoilee sen kokonaisessa lausemuodossa esitetyksi ja samalla korvaa kysymyksessä käytetyn tehdä-verbin syödä-verbillä:@ nosyyään@vaikka£mämmiä£sit. Ohjaaja myös ilmentää huvittuneisuutta suhteessa Marin vastaukseen: hän hymyilee ja muuttaa ääntään lepertelevämmäksi. Mari korjaa vastaustaan ohjaajan uudelleenmuotoilun seu- rauksena toistamalla sen predikaatti-objekti -rakenteen. Lopuksi ohjaaja vielä vahvistaa toistetun vastauksen kelvollisuuden uudella toistolla ja suoralla vahvistavalla palautteella: sekäy.

Esimerkissä 7 ohjaajan ratkaisu korjata alkuperäistä kysymystään esittämällä se lyhyemmässä muodossa riittää jo auttamaan Maria vastaamaan kysymykseen tarkoituksenmukaisesti. Oppilaan kaikuvastauksia sisältävistä kysymyssekvensseistä opettajan tai ohjaajan korjausvuoroineen saattaa kuitenkin muodostua myös pitkiä ja jankkaavia. Viimeinen esimerkki 8 autismiopetusryhmästä on tällaisesta tilanteesta. Kyseessä on toisen koulunkäynninohjaajan ja Marin välinen keskustelu kuluneen koulupäivän tapahtumista. Mari ja ohjaaja istuvat vastatusten ja Marin tehtävänä on kirjoittaa keskustelun pohjalta lyhyitä lauseita vihkoon päivän aikana tehdyistä asioista. Tässä esimerkissä puhutaan käsityön tunnista ja siellä tehdyistä asioista. 


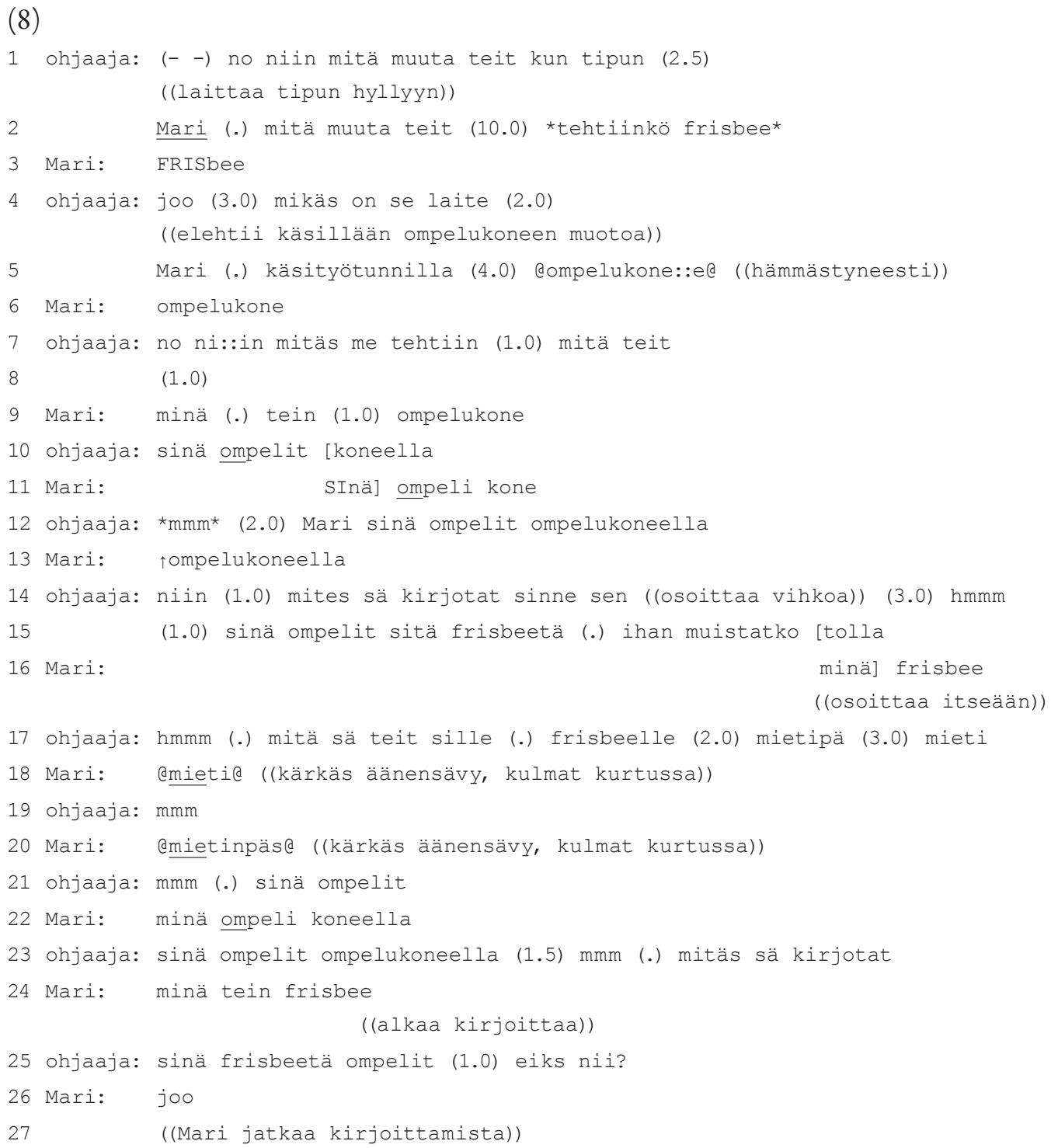

Ohjaajan hakema vastaus rivillä 1 esittämäänsä kysymykseen mitä muuta teit kun tipun on kirjoittaa vihkoon: "Minä ompelin frisbeen". Tämä selviää sekvenssin lopussa riveillä 23 ja 25. Ohjaajan kysymykset hämmentävät kuitenkin Maria, ja niitä seuraa joko pitkät tauot ilman vastaamista tai Marin toistava reaktio. Ohjaajan ensimmäinen moniosainen kysymysvuoro (ks. Linell, Hofvendahl \& Lindholm, 2003) sisältää ensin kaksi hakukysymystä (mitä muut teit kun tipun ja
Mari (.) mitä muuta teit), joista kumpaankaan ohjaaja ei saa pitkän tauonkaan jälkeen vastausta, vaikka yrittää jälkimmäisessä kysymyksessä kiinnittää erityisesti Marin huomion puhuttelemalla häntä etunimellä. Nämä kysymykset eivät myöskään tarjoa sopivaa toistettavaa elementtiä Marille. Sen sijaan moniosaisen kysymysvuoron viimeiseen kysymykseen, niin sanottuun vaihtoehtokysymykseen tehtiinkö frisbee, Mari tuottaa myöntävän vastauksen toistamalla voimakkaasti objektin 
frisbee. Vaikka tällaisessa kysymysrakenteessa kysymyksen sisältämän tehtiin-verbin toistaminen olisi tavanomainen myöntävä vastaus kysymykseen, ohjaaja hyväksyy Marin toiston vastaukseksi dialogipartikkelilla joo. Kun Mari ei jatka vuoroaan pidemmälle, ohjaaja alkaa johdatella Maria lauseen predikaatin, ommella-verbin löytämiseen.

Ommella-verbiin johdattelu tapahtuu ompelukone-sanan hakemisen kautta. Rivillä 4 olevaan hakukysymykseen mikäs on se laite ohjaaja ei saa Marilta taaskaan vastausta, vaan joutuu itse tuottamaan sen Marin ajattelua suuntaavien vihjeiden (Mari (.) käsityötunnilla) jälkeen. Oikea vastaus on ompelukone, jonka Mari myös asianmukaisesti toistaa rivillä 6. Vaikka ohjaajan tarkoituksena on ompelukone-sanan avulla tarjota Marille vihje ommella-verbistä, siitä muodostuu keskustelussa ongelma ja Mari toistaa (ompelu)kone-sanan eri muodoissaan yhteensä viisi kertaa (rivit 6, 9, 11, 13, ja 22). Ensimmäisen ompelukonesanan toiston jälkeen ohjaaja palaa no ni::in -siirtymäkommentin (VISK, 2004, § 798) jälkeen riveillä 1-2 esittämiinsä alkuperäisiin kysymyksiin mitäs me tehtiin ja mitä teit -hakukysymyksillään. Kaksiosaisen kysymysvuoron jälkimmäiseen hakukysymykseen Mari osaa jo tuottaa vastaukseksi kolmisanaisen lauseen, joka ei kuitenkaan ole oikea ja jossa Mari kierrättää ongelmalliseksi muodostuvaa ompelukone-sanaa: minä (.) tein (1.0) ompelukone. Ohjaaja korjaa Marin vastausta rivillä 10 tarjoamalla nyt oppilaalle oikean verbin 'ommella': sinä ompelit [koneella.

Ohjaajan ommella-verbin käyttöä seuraa ymmärtämisen ongelma. Mari toistaa ohjaajan lauseen mekaanisen oloisesti käyttäen siinä samaa ohjaajan käyttämää persoonapronominia sinä, vaikka vaihtuikin itse puhujaksi ja vaikka tunnin tehtävänä on ollut kertoa nimenomaan omasta tekemisestä käsityön tunnilla. Ohjaaja ottaa Marin toiston vastaan empimisäänteellä, mutta tarjoaa tauolla Ma- rille mahdollisuuden jatkaa vuoroaan. Kun jatkoa ei tule, ohjaaja toistaa vielä aiemman lauseensa Mari sinä ompelit ompelukoneella korostamalla lauseen sisällön koskevan nimenomaan Maria häntä nimeltä kutsumalla. Tämän seurauksena Mari toistaa ompelukone-sanan neljännen kerran (rivi 11), tällä kertaa samassa muodossa kuin ohjaajakin teki. Ohjaaja ottaa Marin toiston vastaan dialogipartikkelilla niin ja palaa sen jälkeen varsinaiseen tehtävänantoon, jonka mukaisesti Marin pitäisi kirjoittaa mainittujen frisbee-, ommella-, sinä- ja ompelukone-sanojen perusteella lause siitä, mitä hän teki käsityön tunnilla. Vuorossaan ohjaaja viittaa vihkoon kirjoittamiseen sekä sanallisesti (mites sä kirjotat sinne sen) että vihkoa osoittaen sekä tuottaa vuoronsa keskellä epäsuorasti myös jo oikean vastauksen: sinä ompelit sitä frisbeetä.

Rivillä 16 Mari aloittaakin vastauksen oikealla persoonapronominilla minä, osoittamalla itseään sekä toistamalla frisbee-sanan. Marin lauseesta puuttuu kuitenkin edelleen hankalaksi osoittautunut verbi ommella, minkä hakemiseen ohjaaja kuitenkin edelleen kiinnittyy. Hän kysyy tällä kertaa yleisen mitä teit-hakukysymyksen sijaan tarkennetun hakukysymyksen mitä sä teit sille (.) frisbeelle. Kysymyksen muoto viittaa siihen, että vastauksessa ei voi toistaa tehdä-verbiä, vaan sen tilalle täytyy löytää jokin muu verbi. Kun ohjaaja ei saa heti Marilta vastausta uuteen kysymykseensä, hän yrittää saada Maria ratkaisemaan ongelmaa ehdottavalla kehotuksella mietipä sekä suoremmalla käskyllä mieti. Miettimään patistaminen on epätyypillinen kehotus, joka vihjaa siihen, ettei Mari olisi ajatellut tai yrittänyt tosissaan ratkaista tehtävää aiemmin (ks. myös Mikesell, 2009). Käsky otetaankin sen mukaisesti vastaan Marin vuorossa: Mari toistaa käskyn kahdesti ärtyneellä äänensävyllä ja kulmat kurtussa. Lisäksi jälkimmäiseen, yksikön ensimmäisessä persoonassa ilmaistuun toistoon liitet- 
ty sävypartikkeli -päs ilmentää ponnekasta ja päivittelevää suhtautumista kehotukseen (VISK, 2014, 834).

Ohjaaja ottaa Marin molemmat ohjailevien lausumien toistot vastaan minimipalautteella $m m m$ ja antaa sen jälkeen vihjeen vihkoon kirjoitettavan lauseen alusta: sinä ompelit. Tällä kertaa Mari tuottaa vastauksenaan kolmisanaisen lauseen, jossa hän muuttaa persoonapronominin sinä puhujan vaihtumista oikein ilmentäväksi persoonapronominiksi minä ja käyttää vastauksessaan ensimmäisen kerran ohjaajan kaipaamaa ommella-verbiä - tosin ilman persoonapäätettä (rivi 22). Lisäksi hän liittää lauseeseensa adverbin koneella oikeassa taivutusmuodossaan. Ohjaaja vahvistaa ensin Marin vastauksen toistamalla sen oikeassa verbimuodossa. Koska Mari ei kuitenkaan vielä ryhdy kirjoittamaan, ohjaaja esittää vielä kirjoittamista koskevan jatkokysymyksen mitäs sä kirjotat. Mari vastaa kysymykseen muuten oikein ottamalla lauseeseensa mukaan myös oikean objektin, frisbeen, mutta korvaa nyt odotetun ommellaverbin tehdä-verbillä. Vaikka lause on frisbeen sijapäätteen puuttumista lukuunottamatta oikein muodostettu sekä kielellisesti että merkityssisällöltään, ohjaaja korjaa tehdäverbin tilalle ommella-verbin. Mari hyväksyy korjauksen ohjaajan samanmielistä kantaa hakevan liitekysymyksen eiks niin jälkeen dialogipartikkelilla joo ja alkaa kirjoittaa lausetta vihkoon.

Tässä esimerkissä oppilaan toisto osoitti hämmennystä ohjaajan kysymysten suhteen ja toimi samalla korjausaloitteena. Ohjaaja antoi Marille toistuvasti erilaisia tarjoumia ja näihin tarjoumiin Mari reagoi toistolla. Erityisesti ompelukone-sanan toisto muodostui ongelmalliseksi, kun ensisijaisena tarkoituksena oli löytää ommella-verbi. Esimerkissä ilmeni myös viitteitä mekaanisesta kaiuttamisesta silloin, kun Mari ei muokannut toistettavaa ilmausta persoonamuodoltaan itselleen so- pivaksi, vaan toisti ohjaajan vuoron tämän käyttämässä yksikön toisessa persoonassa (sinä ompeli kone). Tämä persoonamuodoltaan muokkaamaton toisto jäi kuitenkin ainoaksi, sillä muutoin Mari muutti toistettavat ilmaisut persoonamuodoltaan yksikön ensimmäiseksi persoonaksi puhujaksi vaihtuessaan ja itseensä viitatessaan (esim. sinä ompelit -> minä ompeli).

Voidaan myös ajatella, että esimerkissä kuvatun tilanteen tenttaava luonne sekä ainoastaan yhden kielellisesti oikean vastauksen vaatiminen (ei tebd $\ddot{a}$-verbi, vaan ommella-verbi) heikensivät Marin mahdollisuuksia ottaa kaikkia kielellisiä resurssejaan käyttöönsä hänen yrittäessään seurata ohjaajan rakentamaa agendaa. Vaikka kysymyksillä siis pyrittiin auttamaan Maria tuottamaan oikean lauseen vihkoon, ne pitkittivät keskustelua ja synnyttivät uusia korjausvuoroja. Samalla toisto kuitenkin osoitti Marin olevan tietoinen vuorottelukäytännöistä ja odotuksesta vastata koulunkäynninohjaajan vuoroihin (ks. Mikesell, 2010), vaikkei hän osoittanutkaan ymmärtävänsä, millaista responssia häneltä kulloinkin odotettiin. Lisäksi toistaminen palveli koulunkäynninohjaajan lausumien ratifioijana (esim. rivi 3) ja odotetun oikean vastauksen toistona (esim. rivi 6).

\section{POHDINTA}

Tässä tutkimuksessa tarkastelimme, mitä oppilaat tekivät opettajan vuoroja tai niiden osia kaiuttavilla ilmaisuillaan sekä miten opettaja otti oppilaiden kaiuttavat responssit vastaan. Tutkimustulokset vahvistavat aikaisemmissa tutkimuksissa saatuja tuloksia kaikupuheen moninaisista vuorovaikutuksellisista tarkoituksista (ks. Mikesell, 2009, 2010; Saldert \& Hartelius 2011; Sterponi \& Shankey, 2014; Stribling ym., 2007) ja samankin oppilaan erilaisista tavoista käyttää kaiuttamista eri tilanteissa (ks. Mikesell, 2010; Sterponi \& 
Shankey, 2014). Toisin kuin kaikupuheen perinteisessä määritelmässä (ks. esim. Prizant, 1983), oppilaiden kaikupuhe ei ollut tässä tutkimuksessa juurikaan mekaanista kaiuttamista, mitä ilmensi ennen kaikkea valikoiva ja osittainen toistaminen: oppilaat valitsivat opettajan edellisestä vuorosta tyypillisesti vain osan toistettavaksi ja jättivät heille merkityksettömän tai vähemmän tietoa sisältävän osan huomioimatta (ks. myös Svennevig, 2004). Lisäksi oppilaat muokkasivat kaiutettavaa ilmaisua sekä prosodisesti että kielellisesti esimerkiksi muuttamalla sen sijapäätettä tai vaihtamalla verbin tapaluokkaa. Samankin oppilaan toistamat ilmaisut olivat myös keskenään erilaisia, ja joskus toistettava ilmaus läheni opettajan tai koulunkäynninohjaajan ilmaisua prosodisesti tai jäi muodoltaan täysin identtiseksi sen kanssa. Jos identtinen toisto ei sopinut kieliopillisesti oppilaan vuoroon, se antoi viitteitä tässä tutkimuksessa harvinaisesta mekaanisesta toistosta.

Toistettavan ilmaisun muokkaamisesta huolimatta oppilaat eivät kuitenkaan laajentaneet toistoa yhdistämällä siihen esimerkiksi samanmielisyyden osoittamisessa dialogipartikkelia (vrt. Svennevig, 2003). Kaikupuhe edustikin yleensä yhden sanan mittaista ja vähemmän lausemaista vuoroa. Vaikka tällainen ilmaisun lyhyys saattaa yleensä kertoa oppilaiden käytössä olevien kielellisten resurssien rajallisuudesta, kaikupuheen yhteydessä toistettavan ilmauksen pituus ei näyttäisi kuitenkaan liittyvän vahvempaan kielelliseen osaamiseen. Pikemminkin yhden olennaisen avainsanan löytäminen opettajan tai ohjaajan vuorosta ja sen toistaminen viestivät usein toiston merkityksellisyydestä vuorovaikutuskontekstissaan.

Oppilaiden kaiuttavia vuoroja esiintyi responsseina niin opettajan uutta tietoa esitteleviin lausumiin, kysymyksiin kuin ohjaileviin lausumiinkin. Opettajan tai koulunkäynninohjaajan esitteleviin lausumiin vastaamises- sa kaikupuhe palveli sekä tiedon vastaanottamista, oman kielellisen kompetenttiuden vahvistamista sanojen maistelun avulla että affektiivisuuden, kuten innostuneisuuden, ilmentämistä. Huomioitavaa oli, että myös opettajat saattoivat puheensa prosodisilla piirteillä ja katseellaan nostaa toistettavan ilmaisun vuoronsa muita sanoja enemmän esille, jolloin toisto oli eräällä tavalla opettajan ja oppilaan yhdessä tuottamaa.

Opettajan tai koulunkäynninohjaajan uutta tietoa esittelevien vuorojen tai niiden osien kaiuttaminen jäi luokkahuonekeskusteluissa suurelta osin meneillään olevan sekvenssin päättäväksi vuoroksi (ks. myös Svennevig, 2004). Opettaja jätti toiston tässä yhteydessä joko huomioimatta tai osoitti hyväksyvänsä sen minimiresponsseilla (esim. "mm", "ni", "joo"), minkä jälkeen hän ohitti kaiuttamisen nopeasti palaamalla omaan puheenaiheeseensa. Oppilaan toistamasta sanasta ei myöskään koskaan esitetty kysymyksiä tai herätelty yhteistä keskustelua, vaikka aineistossa oli myös esimerkkejä opettajan tavasta käsitellä esittelevien lausumiensa toistoa niiden ymmärtämisen ongelmiin viittaavina korjausaloitteina (Haakana ym., 2016; Lilja, 2010, 2014). Tällöin opettaja laajensi alkuperäistä sekvenssiä ja rikastutti kerrontaansa oppilaan toistamasta sanasta. Opettaja puuttui poikkeuksellisesti sammuttamalla kaikupuheeseen ainoastaan silloin, kun toisto esitettiin kovalla äänellä ryhmätilanteessa, se alkoi hallita luokkakeskustelua tai sen sekventiaalinen asema oli vuorottelun sääntöjen kannalta ei-odotuksenmukainen.

Opettajan tai koulunkäynninohjaajan kysymyslauseen osien kaiuttaminen toimi oppilaan keinona ottaa puheenvuoro silloin, kun hän tiedosti sitä häneltä odotettavan mutta ei osannut tuottaa kysymykseen varsinaista vastausta (ks. myös Mikesell, 2009). Vaikka kysymysten osien kaiuttaminen muotoutui oppilaiden toistavista responsseista ongelmallisim- 
maksi vuorovaikutuksen sujuvan etenemisen kannalta, toistamisen sekventiaalinen paikka oli tässä odotuksenmukaisempi kuin opettajan väitelauseen toistamisessa, jossa opettajan puhe ei edellyttänyt oppilaalta responssia eikä oppilaalle tarjottu puheenvuoroa. Näin ollen vaikka oppilaat eivät osanneet tuottaa oikeaa vastausta opettajan kysymyksiin, he osoittivat pystyvänsä orientoitumaan vuorottelun sääntöihin ja toimimaan niiden mukaisesti. Myös opettajan tai koulunkäynninohjaajan ohjailevan lausuman toistaminen saattoi palvella ymmärryksen ongelman osoittimena hämmentävässä tilanteessa, mutta suurimmassa osassa tilanteita se toimi oppilaan toiminnanohjauksellisena itsepuheena, jota seurasi kaiutettavan ilmaisun mukainen toiminta.

Opettajien ja koulunkäynninohjaajien tavat vastata oppilaiden kaikuvastauksiin poikkesivat selvästi heidän tavoistaan vastata ohjailevien lausumien tai tietoa esittelevien lausumien toistamiseen. He käsittelivät oppilaiden toistavia ilmauksia korjausaloitteina ja pyrkivät siten saamaan oppilaan vastaamaan alkuperäiseen kysymykseensä aloittamalla korjausprosessin (Haakana ym., 2016; Lilja, 2010, 2014). Toisin kuin uutta tietoa esittelevien lausumien toistoon joskus liittyvissä korjausvuoroissa, joissa opettaja pyrki selittämään juuri toistetun sanan merkitystä, kysymyssekvensseissä opettajan korjausvuoro ei kiinnittynyt oppilaan toistaman sanan selittämiseen, vaan oman kysymyksensä muokkaamiseen. Korjausprosessi eteni tällöin siten, että opettaja tai ohjaaja toisti alkuperäisen kysymyksensä, uudelleenmuotoili sitä tai tarjosi muulla tavoin sanallisia tai visuaalisia vihjeitä vastaamiseen. Koska tässä kysymykset siis vaativat oppilaalta ymmärtämisen osoittamista, oppilaiden toistavat vuorot eivät myöskään toimineet sekvenssin päättäjinä, vaan pikemminkin osoituksena kysymyssekvenssin ja asian käsittelyn jatkamisen tarpeesta. Seurauksena saattoi olla pitkä korjausjakso, jossa opettajan kysymyksen uudelleenmuotoilut ja oppilaan toistavat reaktiot vuorottelivat ennen molempia osapuolia tyydyttävään lopputulokseen ja yhteiseen ymmärrykseen pääsemistä.

\section{LOPUKSI}

Tämän tutkimuksen tulokset osoittavat luokkahuoneessa esiintyvien oppilaiden kaiuttavien ilmaisujen moninaisuuden niin niiden merkitysten, niitä edeltävien vuorojen tehtävien kuin niitä seuraavien responssienkin suhteen. Samalla tulokset haastavat oletuksen kaikupuheesta ei-kommunikatiivisena, asiaankuulumattomana tai keskustelun etenemisen kannalta epäolennaisena puheena. Sen sijaan tutkimustulokset havainnollistavat, ettei lapsen kielellinen häiriö rajaa tai kapeuta kaiuttavien ilmaisujen merkityksiä, vaan keskustelukumppanin vuoron tai sen osan toistoa käytetään palvelemaan myös samoja vuorovaikutuksellisia tehtäviä kuin missä tahansa kielellisesti symmetrisessä keskustelussa. Vaikka kaikupuheen on siis havaittu liittyvän joihinkin kielellisiin häiriöihin, sen saamia merkityksiä on tarkasteltava aina vuorovaikutuksellisessa kontekstissaan, eikä lähtökohtaisesti ainoastaan poisopittavana ilmiönä.

Opettajan tai koulunkäynninohjaajan käsitykset kaikupuheesta vaikuttavat paljolti siihen, miten he suhtautuvat ja vastaavat oppilaiden kaiuttaviin responsseihin. Näin ollen he tarvitsevat taitoa tunnistaa oppilaiden kaiuttavien ilmaisujen ja niiden prosodisten vaihtelujen merkityksiä (ks. Saldert \& Hartelius, 2011; Sterponi \& Kirby, 2016; Sterponi \& Shankey, 2014). Koska tässäkin tutkimuksessa oppilaiden havaittiin toistavan aikuisen edellisestä vuorosta vain osan, toistaminen tarjoaa parhaimmillaan opettajalle tärkeän tulkintaresurssin siitä, minkä osan ilmaisusta oppilas tuottaa milloinkin hämmästyksen tai 
hyväksynnän kohteeksi. Esimerkiksi oppilaiden kaikuvastaukset kysymyssekvensseissä kertovat opettajalle, millaiset kysymysrakenteet, käsitteet tai ohjeistukset synnyttävät oppilaassa hämmennystä ja vahvistavat näin epätarkoituksenmukaista kaiuttamista (ks. myös Finlay \& Antaki, 2012; Stiegel, 2015). Tämä edellyttää opettajalta oppilaiden yhden sanan mittaisten aloitteidenkin huomioimista ja niiden laajentamista esimerkiksi kysymysten ja selittämisen avulla.

Mahdollisista kielteisistä mielleyhtymistään huolimatta kaikupuhe ilmentää lapsen vuorottelun ja keskustelukumppanin puheeseen orientoitumisen taitoja, joita ei ole syytä menettää. Samalla oppilaiden kaikupuhetta voidaan käyttää opetuksellisena voimavarana (ks. esim. Kodak, Fuchtman \& Paden, 2012; Leung \& Wu, 1997; Neely, Gerow, Rispoli, Lang \& Pullen, 2016) ja vahvistaa oppilaiden kielellisiä taitoja ohjaamalla oppilasta oikean vastauksen tai olennaisten asioiden toistamiseen esimerkiksi opetuksellisen puheen prosodisten piirteiden vaihtelua ja kuvakommunikaatiota hyödyntämällä. Sen sijaan riskinä on lapsen passivoituminen, mikäli rajalliset kielelliset resurssit omaavan oppilaan kaiuttamista pyritään sammuttamaan eikä hänellä ole muuta vuorovaikutuksessa olemisen tapaa kaiuttavan puheen tilalla (ks. myös de Faria Saad \& Goldfeld, 2009).

\section{LÄHTEET}

Benjamin, T. \& Walker, T. (2013). Managing problems of acceptability through high risefall repetitions. Discourse processes, 50, 107-138. Bottema-Beutel, K., Louick, R. \& White, R. (2015). Repetition, response mobilization, and face: analysis of group interactions with a 19-year-old with Asperger syndrome. Journal of Communication Disorders, 58, 179-193.

Couper-Kuhlen, E. (1996). The prosody of repetition: On quoting and mimicry. Teoksessa E. Couper-Kuhler \& M. Selting (toim.), Prosody in conversation (s. 366-405). Cambridge, UK: Cambridge University. Studies in Interactional Sociolinguistics 12.

da Cruz, F. M. (2010). Verbal repetitions and echolalia in Alzheimer's discourse. Clinical Linguistics \& Phonetics, 24, 848-858.

de Faria Saad, A. G. \& Goldfeld, M. (2009). Echolalia in the language development of autistic individuals: A bibliographical review. Pró-Fono $R$. Atual. Cient, 21, 255-260.

Dobbinson, S., Perkins, M. R. \& Boucher, J. (1998). Structural patterns in conversations with a woman who has autism. Journal of Communication Disorders, 31, 113-134.

Finlay, W.M. L. \& Antaki, C. 2012. How staff pursue questions to adults with intellectual disabilities. Journal of Intellectual Disability Research, 56, 361-370.

Foxx, R. M., Schreck, K. A., Garito, J., Smith, A. $\&$ Weisenberger, S. (2004). Replacing the echolalia of children with autism with functional use of verbal labeling. Journal of Developmental and Physical Disabilities, 16, 307-320.

Grossi, D., Marcone, R., Cinquegrana, T. \& Gallucci, M. (2012). On the differential nature of induced and incidental echolalia in autism. Journal of Intellectual Disability Research, 57, 903-912.

Haakana, M., Kurhila, S., Lilja, N. \& Savijärvi, M. 2016. Kuka, mitä, häh? Korjausaloitteet suomalaisessa arkikeskustelussa. Virittäjä, 120, 255-293.

Heritage, J. (1984). Garfinkel and ethnomethodology. Cambridge: Polity Press.

Heritage, J. (2001). Goffman, Garfinkel and conversation analysis. Teoksessa M. Wetherell, S. Taylor \& S. Yates (toim.), Discourse theory and practice (s. 47-56). London: Sage

Heritage, J. \& Raymond, G. (2005). The terms of agreement: indexing epistemic authority and subordination in talk-in-interaction. Social Psychology Quarterly, 68, 15-38.

Kodak, T., Fuchtman, R. \& Paden, A. (2012). A comparison of intraverbal training procedures for children with autism. Journal of Applied Behavior Analysis, 45, 155-160

Lepistö, T. (2009). Puheen ja ei-kielellisten äänten käsittely aivokuorella autismissa ja Aspergerin oireyhtymässä. Psykologia, 44, 200-205. 
Leskelä, L. \& Lindholm, C. (2012). Näkökulmia kielellisesti epäsymmetriseen vuorovaikutukseen. Teoksessa L. Leskelä \& C. Lindholm (toim.), Haavoittuva keskustelu. Keskustelunanalyyttisia tutkimuksia kielellisesti epäsymmetrisestä vuorovaikutuksesta. Helsinki: Kehitysvammaliiton tutkimuksia 6.

Leung, J.-P. \& Wu, K.-I. (1997). Teaching receptive naming of Chinese characters to children with autism by incorporating echolalia. Journal of Applied Behavior Analysis, 30, 59-68.

Lilja, N. (2010). Ongelmista oppimiseen. Toisen aloittamat korjausjaksot kakkoskielisessä keskustelussa. Jyväskylä Studies in Humanities 146. Jyväskylän yliopisto.

Lilja, N. (2014). Partial repetitions as other-initiations of repair in second language talk: Reestablishing understanding and doing learning. Journal of Pragmatics, 71, 98-116.

Linell, P., Hofvendahl, J. \& Lindholm, C. (2003). Multi-unit questions in institutional interactions: Sequential organizations and communicative functions. Text, 23, 539-571.

McMorrow,M. J., Foxx,R. M., Faw, G. D. \& Bittle R. G. (1987). Cues-pause-point language training: Teaching echolalics functional use of their verbal labeling repertoires. Journal of Applied Behavior Analysis, 20, 11-22.

Mikesell, L. (2009). Conversational practices of a frontotemporal dementia patient and his interlocutors. Research on Language and Social Interaction, 42, 135-162.

Mikesell, L. (2010). Repetitional responses in frontotemporal dementia discourse: Asserting agency or demonstrating confusion? Discourse Studies, 12, 465-500.

Neely, L., Gerow, S., Rispoli, M., Lang, R. \& Pullen, N. 2016. Treatment of echolalia in individuals with autism spectrum disorder: A systematic review. Review Journal of Autism and Developmental Disorders, 3, 82-91.

Niemelä, M. (2011). Multimodaaliset keinot arkikertomuksissa. Teoksessa P. Haddington \& L. Kääntä (toim.), Kieli, keho ja vuorovaikutus. Multimodaalinen näkökulma sosiaaliseen toimintaan (s. 49-64). Helsinki: Suomalaisen Kirjallisuuden Seura. Toimituksia 1337.

Niemi, J. (2008). Prosodia ja autismi. Uusia menetelmällisiä näkökulmia. Pube ja kieli, 28, 117-128.
Park, Y. (2011). The use of reversed polarity repetitional questions during history taking. Journal of Pragmatics, 43, 1929-1945.

Prizant, B. M. (1983). Language acquisition and communicative behavior in autism: Toward an understanding of the "whole" of it. Journal of Speech and Hearing Disorders, 48, 296-307.

Saldert, C. \& Hartelius, L. (2011). Echolalia or functional repetition in conversation - a case study of an individual with Huntington's disease. Disability and Rehabilitation, 33, 253-260.

Schegloff, E. A. (1997). Practices and actions: boundary cases of other-initiated repair. Discourse Processes, 23, 499-545.

Seppänen, E-L. (1997). Vuorovaikutus paperilla. Teoksessa L. Tainio (toim.), Keskustelunanalyysin perusteet (s. 18-31). Tampere: Vastapaino.

Sorjonen, M-L. (1996). On repeats and responses in Finnish conversations. Teoksessa E. Ochs, E. A. Schegloff \& S. A. Thompson (toim.), Interaction and grammar (s. 277-327). Cambridge, UK: Cambridge University. Studies in Interactional Sociolinguistics 13.

Sterponi, L. \& Kirby, K. (2016). A multidimensional reappraisal of language in autism: Insights from a discourse analytic study. Journal of $\mathrm{Au}$ tism and Developmental Disorders, 46, 394-405.

Sterponi, L. \& Shankey, J. (2014). Rethinking echolalia: Repetition as interactional resource in the communication of a child with autism. Journal of Child Language, 41, 275-304.

Stiegler, L. N. (2015). Examining the echolalia literature: Where do speech-language pathologists stand? American Journal of Speech-Language Pathology, 24, 750-762.

Stivers, T. (2005). Modified repeats: One method for asserting primary rights from second position. Research on Language and Social Interaction, 38, 131-158.

Stribling, P., Rae, J. \& Dickerson, P. (2007). Two forms of spoken repetition in a girl with autism. International Journal of Language \& Communication Disorders, 42, 427-444.

Svennevig, J. (2003). Echo answers in native/nonnative interaction. Pragmatics, 13, 285-309.

Svennevig, J. (2004). Other-repetition as display of hearing, understanding and emotional stance. Discourse Studies, 6, 489-516. 
Tarplee, C. \& Barrow, E. (1999). Delayed echoing as an interactional resource: A case study of a 3-year-old child on the autistic spectrum. Clinical Linguistics \& Phonetics, 13, 449-482.

Trevor, B. \& Walker, T. (2013). Managing problems of acceptability through high rise-fall repetitions. Discourse Processes, 50, 107-138.

Vakil, S., Welton, E., O'Connor B. \& Kline, L. S. (2009). Inclusion means everyone! The role of the early childhood educator when including young children with autism in the classroom. Early Childhood Education Journal, 36, 321326.
Valentino, A. L., Shillingburg, M. A., Conine, D. E. \& Powell, N.M. (2012). Decreasing echolalia of the instruction "say" during echoing training through use of the cues-pause-point procedure. Journal of Behavioral Education, 21,315-328.

VISK = Hakulinen, A., Vilkuna, M., Korhonen, R., Koivisto, V., Heinonen, T. R. \& Alho, I. (2004). Iso suomen kielioppi. Helsinki: Suomalaisen Kirjallisuuden Seura. Verkkoversio. Saatavissa: http://scripta.kotus.fi/visk/etusivu.php.

Wong, J. (2000). Repetition in conversation: a look at "first and second sayings". Research on Language and Social Interaction, 33, 407-424.

\section{THE FUNCTIONS OF STUDENT ECHOLALIC SPEECH IN LINGUISTICALLY ASYMMETRIC CLASSROOM CONVERSATIONS}

Tanja Vehkakoski, University of Jyväskylä

Anja Rantala, University of Jyväskylä

Repeating the words of the conversational partners gives the persons with restricted communicative abilities a possibility for taking an active part in and exerting some control in the conversational interaction. Earlier research has approached the repeats with two different viewpoints: they have been considered either as problematic and meaningless echolalia, or as motivated communication meaningful for speakers themselves. This paper examines the functions for which students with special needs use repetition in their interaction with teachers and the ways in which teachers treat these echolalic responses in classroom talk. The research data consists of the video-recordings of lessons in one special education group for autistic children $(\mathrm{N}=11)$ and in one group for students with intellectual disabilities $(\mathrm{N}=9)$. The data were analyzed through conversation analysis. The findings show that the students used repeats either to respond to teacher declarative sentences, questions or directives. By responding with repetitional responses, students seemed to show listening and orientation to the prior turn of the teacher, initiate repair, prompt themselves or learn language. Teachers typically ratified student repeats minimally but their responses varied according to the context of repetition. The education of teachers is important, since children's communicative competence develops mostly in natural everyday learning contexts.

Keywords: classroom interaction, conversation analysis, echolalia, repetition, student, teacher 